https://doi.org/10.18485/iipe_euchanges.2021.ch12

\title{
FRAGMENTING CHINAMERICA AND ITS IMPACTS ON EUROPE: MULTILATERAL TRANSFORMATION OF THE GLOBAL SYSTEM
}

\begin{abstract}
Marek HRUBEC ${ }^{1}$
Abstract: The main aim of the article is an analysis of the contemporary process of multilateral transformation of the global political, economic and security system, particularly the analysis of the problematic US-China interactions and their impact on Europe. It raises a research question on European consequences of fragmenting Chinamerica, i.e., the process of partial decoupling of the economic interdependence of China and the USA, which became influential mainly during the Trump administration, including trade, technological, diplomatic, military and other tensions. It has also survived in the Biden administration even if so far in a less confrontational and more cultivated form. Methodologically taken, the article includes an analysis of the current transformative trends in the political and economic reality and stresses the importance of selected documents and speeches of the strategic relevance presented in the USA, the PR China, and the European Union. The article comes to an explanation of the issue by addressing the historical process of development of Chinamerica (including dual circulation) and its following partial fragmentation (with a possible military escalation, including limited nuclear war), as well as the most recent US and China prospects for the next years and the related European dilemmas on a multilateral global approach and cyber security. The multipolar transformation of the global system is explained in relation to a bigger relative strategic autonomy of the major powers than in the past.

Keywords: Chinamerica, Europe, multilateral, security, transformation, global system, strategic autonomy.
\end{abstract}

${ }^{1}$ Director of the Centre of Global Studies and Coordinator of the Strategic Research Program 'Global Conflicts and Local Interactions' AV21, the Czech Academy of Sciences, Institute of Philosophy and Institute of Sociology, Prague, the Czech Republic. E-mail: marek.hrubec@gmail.com 


\section{INTRODUCTION}

The contemporary process of multilateral transformation of the global political and economic system understandably has its profound impacts on Europe. This process has its harmonious parts as well as its labour pains. While the economic cooperation and interdependence between the USA and China developed since the 1970s, i.e., an integrative process of Chinamerica (Ferguson, 2008; Jones, 2010), a dramatic process of partial decoupling of the economic interdependence of China and the USA has mainly become influential since the Trump administration, including technological, trade, diplomatic and other tensions. Nevertheless, a pivot to East Asia started to play a role already before his administration, and it has survived also in the Biden administration, even if so far in a less confrontational and more cultivated form.

This article focuses on this issue in four parts. First, it analyses the historical process of the development of Chinamerica. It explains that this process has been interlinked to an idea known as dual circulation now. It shows the source of the idea in the early phases of China's reform and opening up in the late 1970s and 1980s. Then, it was developed and reformulated step by step in interactions between the domestic development in China and its activities in the global supply and demand chains, including relations to the Belt and Road Initiative since 2013.

Second, the article deals with the process of fragmentation of Chinamerica, i.e., with the US attempts of decoupling from China under the Trump administration, which also partly decoupled from Europe and other parts of the world. It focuses on an escalation of the US approach to China, which is usually explained only within a framework of trade, technological, and diplomatic kinds of war. This part of the article explains that the US strategic documents of the Trump era could also initiate worse consequences, particularly a possible military escalation, including limited nuclear war. It explains China's approach as well, which includes reactions to the US approach.

The third part deals with the most recent US and China prospects for the next years and their possible thematic overlapping. It shows the contemporary partial reconfiguration of the US approach to the world after the Biden administration took power. However, it still stresses problems with China and mostly ignores Europe, as is apparent in Biden's inaugural address and the first foreign policy speech. Comparatively, the third part also focuses on China in order to see new prospects of development from 
2021 to 2025 and then to 2035 , formulated in relation to the $14^{\text {th }} 5$-year plan and beyond.

In the last, fourth part, the article formulates a place and role of Europe in this complex process of partial fragmentation of Chinamerica in the world. It explains the European dilemmas in relation to its new documents on a multilateral global approach and cyber security. It also mentions the relevant contexts of other global interactions, such as the new Regional Comprehensive Economic Partnership (RCEP) in Asia, for example.

The article intends to stress representative economic, security and political strategic issues to explain the current turbulent theme of fragmenting Chinamerica and its impacts on Europe within the multipolar transformation of the global system. The contemporary reshaping of global interactions means a bigger relative strategic autonomy of major powers than in the past, on the one hand, and bigger possibilities of global cooperation, competition and tensions in other areas, on the other hand.

In this article, I take after a discourse on security and political challenges and opportunities concerning the cooperation between Europe and China and the Belt and Road Initiative which was set up by conferences and books published at the University of Belgrade (Cvetković, 2016; Cvetković, 2018). ${ }^{2}$

\section{CHINA'S ROAD TO A CONCEPT OF DUAL CIRCULATION AND CHINAMERICA}

First, it is important to explain the historical process of the development of Chinamerica. This process was interconnected to an idea which later has been called dual circulation. I will explain the source of this concept in the early phases of reform and opening up in the late 1970s and the 1980s. This concept was developed step by step and reconceptualised in interactions between the internal development in China and its involvement in the global supply and demand chains which has its relevant impacts on China's recent development. ${ }^{3}$

\footnotetext{
${ }^{2}$ I have in mind particularly mainly the cooperation between China and Central and Eastern European countries $(17+1)$, and activities and publications on this topic organised at the Faculty of Security Studies at the University of Belgrade.

${ }^{3}$ In the explanation in this part on dual circulation, I follow my longer analyses where I explained the transition from China's reform to reform efforts in international and global interactions (Hrubec, 2020).
} 
Deng Xiaoping liked the idea of the four modernisations (in the spheres of agriculture, industry, defence, science and technology), and from 1978 he and his team started pursuing an approach that would be consistent with the new era of Chinese history: economic reform and opening up of China to the world (改革开放 gaige kaifang; reform and opening up). He pursued the reform and opening up of China by overhauling production and commerce domestically and globally. In particular, China offered its cheap workforce and factory production capacity, thereby forging pragmatic economic connections between China and Western countries, particularly with the USA and Western European countries (Góralczyk, 2018). 1978 was a very important year because China's transformation and opening up also laid the foundations for a global supply chain.

The relationship between the internally (domestic) and externally (foreign) oriented models is important here as a source of dual circulation. While many developing countries were forced to quit their own internal model and accept the Western model in order to be allowed to cooperate with it globally, China was able to integrate itself into the global economy but, at the same time, to keep and develop its own domestically more appropriate model (Nolan, 2019). Though each partner (China and the West) maintained its own domestic system, there were certain system overlaps and new common global areas. These interactions also changed the US and European economies. This specific kind of interdependence and the integration of different economic concepts yielded a new model for the transnational and global economy: great convergence (Mahbubani, 2014), even if first mainly under the Western leadership. The USA and Western Europe and other parts of the world have become part of global China and vice versa. The concept of 'Chinamerica' has stressed how deeply internally interdependent the Chinese and USA economies are, as clearly demonstrated also by problems caused by the US introduction of tariffs in the recent US-China trade, technological and diplomatic frictions.

Obviously, China was not transformed and opened up in a single day, but that required several stages in which individual elements of reform gradually proved their worth (Vogel, 2013). We can demarcate four basic stages of Chinese development in the past 40 years, with a gradual increase in global interactions. The first stage stretches back to the beginning of the reforms in 1978. The second stage started in 1992 when the market's important role was officially institutionalised, and work was genuinely launched on combining the market with planning (Wei, 2010). The third stage, from 2001, saw China joining the WTO and integrating 
comprehensively into the global economy. The country became indispensable to world production and trade. The fourth stage took hold when the Belt and Road Initiative was announced in 2013 and has continued until the present. China was able to cope with various obstacles and tendencies. Overall, China not only integrated itself into the global economy but also partly changed world production and trade.

Crucially, this development triggered an unprecedented increase in the standard of living for more than a billion people in China and many other people across the world. These are not just abstract statistics glossing over the plight of the people, particularly the poor. In the past 40 years, China elevated 800 million people from poverty by 2020 and fully eradicated absolute poverty (Wang, 2015a; Wang 2015b). This was a big improvement in social rights. If we take into account that China has 1.42 billion people (as of 2019 , according to UN data), i.e., $18.4 \%$ of the world population, this social development is an enormous achievement in the history of human civilisation. At the same time, the Chinese government knows that many people are still faced with more meagre standards of living, and it plans to improve the situation in the years to come.

Let's see in bigger detail several main reasons underpinning the successful transformation of China's economic system. It is possible to rely on the standard theory of convergence. Even so, the Chinese economy's rapid growth still facilitated convergence. Here, we need to find an answer to the question of what made this growth possible. The core logic behind the Chinese reform and opening up of the last 40 years was that international trade was not taking place between two countries employing the same system. The Western countries, on the one hand, and China, on the other, had different political and economic models. As David Daokui Li from Tsinghua University stresses, the fact that the Chinese government had to manage the economy in an active way has been considered a relevant factor for rapid economic development (Li et al., 2018). Socialist China had two salient features. First, as it was making significant investments in companies thanks to the rules of banks, it was reporting the large capital returns of a country. Unlike many Western-oriented countries where profit was accumulated and then often inefficiently spent, China also ploughed the profits into social development. Nevertheless, now the Chinese government believes that inequality between people has become a problem to a certain degree, which is the opposite situation to that at the beginning of the reform. Of course, a meritocratic approach has its own limits, even if it has occasioned great improvement in the standards of living of many people. 
There are projects designed to improve the situation, including in parts of China beyond the well-developed East Coast, and to foster a more egalitarian approach in the future. By doing that, it will be important to avoid the middle-income trap found in South Korea and other countries.

Secondly, the Chinese economy's transformation was successful because of the 'big-country effect'. The scope of the economy in the domestic and global interactions is a determining factor. China is not just one of the successful small Asian tigers, but it is characterised by an application of a more influential model: the Flying Dragon Model. This model changed a small, cheap production and trading partner into a major force, following Hegel's developmental idea of the dialectics of the master and labourer via learning through history. A complex process of practical learning through opening up is more important here than individual aspects of reform, i.e., more than a comparative advantage in relation to the West and dependence on foreign capital and technologies ( $\mathrm{Li}$, et al., 2018). The Chinese meritocratic recognition of education and work plays a role here as well.

It was on the strength of this successful transformation of the Chinese economy that makes it possible to refer to 1978 as the second revolution in China. As this is a revolution that did not occur immediately but instead delivered significant changes over the course of several decades, we call it a revolutionary transformation. ${ }^{4}$

The Belt and Road Initiative is one of the consequences of that development. An initiative similar to the Belt and Road Initiative (BRI) might possibly have been suggested later, even without the global economic crisis as the major impetus because China's reform and opening up since 1978 was already going down that path, following the historical Silk Road. Therefore, this foreign policy and initiative adopted by China were a logical consequence consistent with Chinese developments which came into being when President Xi Jinping with his team brought it together into a new concept (Xi, 2017, pp. 543-566). When he announced it officially, he also

\footnotetext{
${ }^{4}$ Understandably, there are also deeper historical preconditions arising before the reform and opening up and underscoring the Belt and Road Initiative. I have two specific stages in mind. First, events in the period after the Xinhai revolution, which saw the overthrow of the Chinese imperial regime in 1911, and the Republic of China from 1912 to 1949 . Secondly, events in the period from the establishment of PR China in 1949, until 1978. However, these older preconditions are not the topic of this article which is limited by length.
} 
mentioned its elements in Chinese medium and long-term history. This was a sign that it was deeply rooted in a chronological context.

The Belt and Road can be considered a new model of global interactions: Globalisation 2.0. The BRI has contributed significantly to the development, inclusion and multipolarity of the world by efforts to cooperate based on mutual recognition of participating partners, with a significant help to developing countries. Since it was announced, the BRI has been developed as a model in Eurasia and Eastern Africa, before going to other parts of the world. Since it has encompassed also Latin America, it is a global project. It fits well with the global tendencies of new alternatives. While we have recently witnessed faltering US unilateralism, at the same time we can see China and other countries introducing a multipolar perspective. This is not limited to the BRICS countries, but also includes Mexico, Indonesia, Turkey, for example, and also various kinds of macro-regional organisations, such as the European Union, the Shanghai Organisation of Cooperation, etc. Russia will continue to be a key partner, including in the Shanghai Organisation of Cooperation.

\section{THE FRAGMENTING RELATIONS BETWEEN THE USA AND CHINA}

While the 'Pivot to Asia', or more specifically 'Pivot to East Asia', was announced and has partly emerged already under the Obama administration, it was not really developed because the government continued to be preoccupied with wars in Islamic countries which were initiated by the previous Bush administration. As it is well known, the real pivot to East Asia, particularly a conflictual pivot to China, was fully materialised by the Trump administration. First, it created trade frictions with tariffs in order to lower the US trade deficit. However, the confrontational approach to China preferred by the Trump administration failed as the US Department of Commerce announced in February 2021: the US trade deficit climbed to 678.7 USD billion in 2020, which is the highest number since the 2008 US economic and financial crisis (American Observer, 2021). Because the results of these trade frictions are often analysed, I will focus on other kinds of tensions.

The US frictions with China also took the form of technological war and diplomatic tensions, including disputes on Hong Kong, Taiwan, Tibet, Xinjiang, and the South China Sea. These territorial tensions were interlinked 
to security issues. I will focus on the tensions of the highest form to show to what extent and what danger the conflicts have escalated under Trump.

Almost 30 years after the Cold War, the Trump administration revitalised the intention to include nuclear weapons into its real military plans and to create a new arsenal of nuclear weapons for the new era. ${ }^{5}$ This could cause enormous direct ravages of war. It was not only a regression into a Cold War mentality. During the Cold War, even if nuclear weapons were marginally considered possible weapons of war as a last resort, their main purpose was different. They served as a deterrent against one's enemies (Gaddis, 2016). While their first use at the end of WWII at Hiroshima and Nagasaki was in fact a test of this kind of weapon of massive destruction, since then they have never been used (Rhodes, 2012). The USA and the USSR developed nuclear weapons under the Mutual Assured Destruction (MAD) doctrine in order to prevent war. Because of potential mutual destruction, the use of nuclear weapons was regarded as 'thinking the unthinkable' for a long time, until now. Not only the superpowers but also other nation-states started to consider their nuclear weapons as a deterrence (Brode, 2014; Craig\&Radchenko, 2008).

However, under the Trump administration, we entered a new epoch of military threats. For the first time in human history, nuclear weapons started being considered practically, not only hypothetically, as real tools for various future-armed conflicts. New US strategic documents, political statements and corporate interests confirmed a change that has been under preparation over the last few years.

The important issue is the difference between the strategy of a global destructive war following classical application of standard nuclear weapons under the Mutual Assured Destruction doctrine, on the one hand, and the new strategic plan of limited nuclear war, without its global continuation, on the other. The possibility of avoiding a planetary catastrophe is redeemed here with the real intention to make nuclear war, even if only on a limited scale.

The relevant document which can explain the main strategic trends in this respect is the National Security Strategy, which has been issued since Ronald Reagan submitted the first one in 1987 (Pee, 2015; Suri\&Valentino,

\footnotetext{
${ }^{5}$ In a broader context, I dealt with the possible US intentions to use nuclear weapons in my analysis based on critical sociology (Hrubec, 2019). I follow it here in the following part on limited nuclear war.
} 
2016). In December 2017, President Trump specified an application of his 'America First' mindset to security issues (National Security Strategy of the USA, 2017). He wanted to be contrasted with what he saw as Obama's appeasement and defeatism. The Strategy identified two major nuclear powers, namely Russia and China, as 'revisionist' powers that are trying to 'shape a world antithetical to US values and interests'. These countries together with several others allegedly attempt to erode US prosperity and security: 'Three main sets of challengers - the revisionist powers of China and Russia, the rogue states of Iran and North Korea, and transnational threat organisations, particularly jihadist terrorist groups - are actively competing against the United States and our allies and partners'. (National Security Strategy of the USA, 2017, p. 25). In several aspects, Trump successfully disrupted the version of the war interventionist approach pursued by the previous US administrations. However, it is clear that Trump's attempt to reverse the US Cold War strategy, i.e., to be hostile to Russia but to cooperate economically with China, failed. Trump managed to reverse the US approach to China, but the US system maintained hostility to Russia. The final result has been deterioration in relations with both countries.

There are similar formulations in the US National Defence Strategy issued in 2018. China is considered a 'strategic competitor' and Russia a similar challenge (both called 'revisionist powers' again) (The Summary of 2018 National Security Strategy of the USA, 2018, p. 2). The Strategy leads to a conclusion that the USA needs to 'build more lethal force', including cyberweapons and nuclear force to counter competitors' coercive power.

The 2018 edition of the Nuclear Posture Review (NPR) offers a detailed specification of the plan for nuclear weapons (U.S. Department of Defence, 2018), made in contrast to Barack Obama's 2010 NPR, which at least formally followed the spirit of his anti-nuclear speech in Prague in 2009 (Obama, 2013; U.S. Military, 2010). By pursuing small (low yield) nuclear weapons, the new 2018 NPR retained not only business as usual but it opened up a new groundbreaking epoch in political and military actions with an intention to make limited nuclear attacks or wars a reality. The US bombing of Hiroshima and Nagasaki was mainly a dramatic escalation of the research application of nuclear power at the end of the World War II, i.e., the first US test of nuclear weapons and not part of the real military strategy. Later, both the Warsaw Pact and NATO countries created not only large nuclear weapons but also smaller tactical ones in the form of short-range missiles and free-fall bombs (i.e., without a guidance system), etc., but these were only part of much larger, global military deterrent projects with major 
strategic nuclear weapons (Brode, 2014). The smaller weapons did not play an autonomous role. And when they were considered by various nuclear nation-states in regional relations after 1989, they were also regarded as a part of deterrence.

Attempts to initiate a discussion on the autonomous use of small nuclear weapons without their inclusion in large military programmes using major nuclear weapons developed especially thanks to new technologies allowing also more precise mutual control of the activities of rivals (Larsen, 2014, pp. 3-20). Whereas since the World War II until recently, nuclear war was used only as a form of deterrence of the enemy, and overwhelmingly not as a real military option, over recent years and especially in the US strategic military documents, a limited nuclear war has started to be considered. The situation has been really serious, which is not an exaggeration because we cannot eliminate the possibility of global escalation of a local limited nuclear war.

Michael Pompeo, US Secretary of State, specified the country which is the biggest threat from the perspective of the US administration in his speech 'Communist China and the Free World's Future' in 2020. The speech is considered a key declaration of confrontation with China as the main world competitor of the USA. It is a talk presented symbolically in the Nixon Presidential Library and Museum, which overturns US relations with China established more than 40 years ago, which began to be negotiated by Kissinger and President Nixon already 50 years ago. While half a century ago the United States reduced its ideological worldview and began cooperating with communist China, Trump and Pompeo see today's complex political and economic system of China as a global threat. In his 2020 speech, Pompeo said to the American people that he wanted to explain what 'the China threat means for our economy, for our liberty, and indeed for the future of free democracies around the world' (Pompeo, 2020).

Similar criticisms of China have already been made in Trump's speeches and related documents, but Pompeo's anti-authoritarian speech is considered a definitive turning point: a point of no return, at least not in the foreseeable future. In this sense, it is very extreme. Even many of China's critics refused Pompeo's aggressive talk by calling it 'Pompeo's surreal speech on China', for example (Wright, 2020).

The US strategic and other documents and related activities stimulated understandably reactions in other parts of the world, already before Pompeo significantly exacerbated the situation. China issued China's National Defence in the New Era in 2019 in order to formulate its own defence approach (China's National Defence, 2019). This White Paper is largely focused on the 
reform and modernisation of the People's Liberation Army (PLA) for the current and future cyber age, as well as a response to the significant transformation of the US approach issued in the National Security Strategy in 2017 and the National Defence Strategy in 2018, which I explained above, i.e., the US shift from focusing on counterterrorism mainly in Islamic countries to rivalry with China and Russia. China understands that it is the first time recently when the USA considers China the main competitor (Cordesman, 2019).

Comparatively taken, as expected, China's defence strategy is formulated in a much more diplomatic way than the US documents. Its wording is rather a cultivated policy paper, as it is typical for Chinese documents. Therefore, it opens less number of problematic issues than the USA. It is significant that the strategy starts with a description of the domestic system dealing with the building of a moderately prosperous society of a modernised socialist country, and leads to the last part which goes beyond military issues and offers a global proposal for humanity called 'Actively Contributing to Building a Community with a Shared Future for Mankind'.

China's National Defence reminds of an enlargement of NATO by stepping up deployment in former socialist countries in Central and Eastern Europe. It stresses that, at the same time, the European Union attempts to integrate its security and defence in order to be more autonomous. The USA, the main European powers, particularly France, and Germany, and other major powers of Japan and India optimise their military forces. The US activities include joint military exercises with NATO partners and others under the de facto unilateral leadership, and also institutional and technological modernisation to keep 'absolute military superiority' (China's National Defence, 2019, pp. 5-6). The White paper considers it an intensification of global military competition. ${ }^{6}$

Nevertheless, in these global interactions, China presents itself as a stable power pursuing a nuclear policy which is described as 'no first use of nuclear weapons at any time and under any circumstances'; it keeps nuclear powers

${ }^{6}$ The document also states attempts to mitigate tensions, particularly that, in 2014, the US Department of Defense and China's Ministry of National Defence issued a document on the Memorandum of Understanding on Notification of Major Military Activities and Confidence-Building Measures Mechanism and also the Memorandum of Understanding Regarding the Rules of Behavior for Safety of Air and Maritime Encounters (China's National Defence, 2019, p. 32). 
at the minimal level for national self-defence, 'to maintain national strategic security by deterring other countries from using or threatening to use nuclear weapons against China' (China's National Defence, 2019, p. 9). It advocates the complete prohibition of nuclear powers, including their destruction.

The aim of the document is to explain the implementation of the military strategic guideline for a New Era, the innovation of military theories, and the continuation of building the military in the Chinese way in order to protect its sovereignty and security. It warns against possible conflicts in relation to Taiwan, the South China Sea, and the Diaoyu Islands as inseparable parts of China. Now in 2021, China's leadership also mentioned similar disputes related to Tibet, Xinjiang, and Hong Kong.

A part of the approach explained in the document, is a model of security partnership that stresses a Chinese concept of win-win cooperation, used also in other spheres such as economics. Together, China and Russia are considered partners that resist the US hegemony. The document also pays attention to regional security cooperation, particularly the Shanghai Cooperation Organisation (China's National Defence, 2019, p. 34), the China-ASEAN Defence Ministers' Informal Meeting, and the ASEAN Defence Ministers' Meeting Plus. As for global cooperation, it is the UN, mainly peacekeeping efforts. The document acknowledged the rivalry announced by the USA, and shows that China is ready to defend itself in a new digital era.

The broader context of China's National Defence in the New Era is a relevant document China and the World in the New Era issued in 2019, the year which is the 70th anniversary of the founding of the People's Republic of China (China and the World in the New Era, 2019). Basically, it explains China's development path for new conditions and shows it as an opportunity for a better world. China presents its intention not to seek hegemony but to contribute to a prosperous world.

\section{THE USA AND CHINA: THE NEW PROSPECTS FOR NEXT YEARS}

The 4-year term of the new Biden administration almost overlaps with China's 14th 5-year plan for economic and social development. Biden's strategy on relations between the USA with China for the next years will influence relations with other countries and macro-regions of the world. The US approach is formulated as an adaptation to its health crisis, economic turbulences, political turmoil, and a global decline of its reputation. I will 
focus more on the US approach than China's one below because the former is more confrontational than the latter, which is essential for their mutual interactions.

Despite all of the domestic and foreign problems, President Biden, in his Inaugural Address presented in January 2021, expresses self-confident proclamation about the US leadership: 'We can make America, once again, the leading force for good in the world', 'We will lead not merely by the example of our power but by the power of our example' (Biden, 2021a). The thesis on leadership was formulated also in the first foreign policy speech that Biden delivered at the State Department in February 2021, which deserves our close attention, as it has been his initial and most articulated speech on global affairs so far. He will certainly give other speeches, but this is symbolic of the setting of the initial framework for his term. Even if it was addressed mainly to the US state department and other domestic offices, it is expressed in many parts as an international speech. Biden stated, 'the message I want the world to hear today: America is back. America is back'; 'we've moved quickly to begin restoring American engagement internationally and earn back our leadership position, to catalyse global action on shared challenges' (Biden, 2021b).

Many people, countries and multilateral organisations in the world have feared that such an unrequired leadership can be pursued. They would welcome if the US first solves its own deep domestic problems and then try to improve step by step its reputation and trust in the world, and not to impose the US erratic state of affairs on others. Moreover, traditional overstated formulations about America are perceived with reservations, especially in Latin America, because as is well known, the USA is not America but only the middle belt in North America. The ambition of a leading political role in the world reveals an exaggerated self-perception and exceptionalism of the new US administration. It has its consequences also in the economic sphere: 'if we fight to ensure that American businesses are positioned to compete and win on the global stage' according to Biden (2021b).

The positive turn of the Biden administration is its proclamation of multilateralism, which will certainly limit the US unilateral approach to a number of issues and organisations. It means re-joining the Paris Climate Agreement and the World Health Organisation, a better approach to the UN in general, overturning the discriminatory Muslim ban, etc.

However, this does not mean that the strengthening of multilateralism and the weakening of unilateralism will bring about a fundamental turn in confrontational policy towards other major powers, particularly to Russia 
and China: 'American leadership must meet this new moment of advancing authoritarianism, including the growing ambitions of China to rival the United States and the determination of Russia to damage and disrupt our democracy'; it is considered 'the new moment ... accelerating global challenges' (Biden, 2021b).

The Biden administration announced a strong competition between the USA and China and, at the same time, an attempt to avoid a conflict. However, it is not valid for relations with Russia which are much more ambivalent. While the START Treaty was prolonged this year, the process of deterioration continues.

As for China specifically, Biden already has experience in dealing with Chinese President Xi Jinping in the Obama times when he negotiated with him from the position of Vice-President. On the one hand, this personal knowledge could help decrease confrontational communication but, on the other hand, it is essential that Biden and his administration are in a different era. Trump's period cannot simply be erased; on the contrary, it will have its prolongation into the period of the Biden administration and probably even longer. This is also evident from Biden's statement: 'we'll also take on directly the challenges posed by our prosperity, security, and democratic values by our most serious competitor, China. We'll confront China's economic abuses; counter its aggressive, coercive action; to push back on China's attack on human rights, intellectual property, and global governance' (Biden, 2021b). This approach and perception of China as a 'most serious competitor' is a very different approach compared to the previous Democratic government, i.e., the Obama administration. Although Biden's approach seems less confrontational and unipolar in comparison with Trump, he finds himself on the border between Obama and Trump, and closer to Trump.

The new US Interim National Security Strategic Guidelines issued in March 2021 write about a 'strategic competition with China' and other issues in a similar way: 'China ... is the only competitor potentially capable of combining its economic, diplomatic, military, and technological power to mount a sustained challenge' (Interim National Security Strategic Guidelines, 2021). On the same day, US Secretary of State Antony Blinken delivered his first address on foreign policy when he said that China represented the 'biggest geopolitical test of the 21st century': 'Our relationship with China will be competitive when it should be, collaborative when it can be, and adversarial when it must be.' (Blinken, 2021) New technologies, including 5G, artificial intelligence, robotics, automation, with 
their possible usage in the military, are the focus of the US administration in order to keep certain regulatory mechanisms to limit China in competition. Global strategic interactions between China and the USA will be based on more complex and structured cooperation with like-minded countries, regions, and macro-regions of the world.

For Biden, Russia as the former Cold War rival is one of two main adversaries in global politics. On the one hand, it is undoubtedly positive that agreement has been reached on the extension of the New START Treaty on nuclear weapons for the next five years since 2021. This 'New Strategic Arms Reduction Treaty' limits the USA and Russia to deploy nuclear weapons maximally to 1,550 each. After the Intermediate-Range Nuclear Forces Treaty expired in 2019, the New START Treaty is the last treaty between the USA and Russia dealing with at least a formal nuclear consensus. However, because of an escalation of various diplomatic and territorial tensions over the last years, there is still a danger of nuclear war. The influential US STRATCOM (United States Strategic Command) head Charles Richard wrote in his article on 'Forging 21st-Century Strategic Deterrence' in February 2021, i.e., under the Biden administration, that 'There is a real possibility that a regional crisis with Russia or China could escalate quickly to a conflict involving nuclear weapons' (Richard, 2021).

Biden explicitly states that he wants to take a very different approach to Russia from that of Trump, saying that tolerance towards Russia has expired: 'the days of the United States rolling over in the face of Russia's aggressive actions...interfering with our elections, cyber- attacks, poisoning its citizens...are over. We will not hesitate to raise the cost on Russia and defend our vital interests and our people. And we will be more effective in dealing with Russia when we work in coalition and coordination with other like-minded partners (Biden, 2021b)'. While the contemporary direct confrontation with China probably eases a little and systemic longer-term tensions increase (even though nobody can avoid a chaotic escalation also in the short term), Biden wants to be tougher against Russia.

Therefore, what does it mean when Biden talks about a return? At first glance, it seems that the new US administration is attempting to return on position before Trump and rehabilitate earlier policies. Already in his inaugural address, Biden said it was: 'A day of history and hope. Of renewal and resolve'; 'Much to repair. Much to restore. Much to heal'. There are many such words with re in his foreign policy speech: re-build, re-pair, reengage, re-store, re-assert, re-instate, re-institute, re-invigorate, etc. In summary, this is expressed in the sentence: 'It's going to take time to rebuild 
what has been so badly damaged' (Biden, 2021b). However, the Biden administration will be only very partially a kind of the third term of the Obama administration. As indicated above in Biden's intentions to China and Russia, when he talks about a return, the word return here means only a direction and not a destination. It does not mean a return to the classical US pattern of relations to Russia and China but rather a partial backwardslooking redefinition of Trump's policy within the limits of the current domestic power constellation in the USA and its foreign preconditions and interactions. At the same time, the US mainstream media, the New York Times, for example, pursue a 'Pompeo-lite' approach to global issues (U.S.' continued deception, deflection, politicization, 2021).

As for Europe, Biden did not mention it in his foreign policy speech at all, which probably says more about his position to Europe than he intended. As if Europe did not exist being abolished by Brexit, only a few fragmented European countries remain in his world: the UK, Germany, France; and NATO.

When focusing on security, Biden emphasises cyberspace: 'We've elevated the status of cyber issues within our government, including appointing the first national -- Deputy National Security Advisor for Cyber and Emerging Technology. We're launching an urgent initiative to improve our capability, readiness, and resilience in cyberspace' (Biden, 2021b). It is focused mainly against Russia but implicitly also against China. National security priorities and foreign policy are to be strengthened by a military presence, according to a Global Posture Review.

To conclude, the new US administration intends to make a partial return on positions before Trump and rehabilitate earlier policies. However, history will not stop. As the ancient Greek philosopher Heraclitus said 2,500 years ago: nobody steps in the same river twice. Biden's partial return is a return to the problematic situation which Trump created. Thus, returning is not the solution but just postponing it. The 4-year Trump administration reformulated the traditional limits of cooperation, competition and conflicts for the foreseeable future. The development of the USA, as well as global development, has been in certain trajectories that cannot be completely changed but only slowed down and partly corrected. Under the Biden administration over the next years, there may also be dramatic moments that, however, would not result directly from characteristics of his administration, but rather from the deeper characteristics of the long-term development. Therefore, it would not be smart to underestimate it. There will be the three basic strategic US approaches in relations to China and Russia: cooperation 
(the pandemic, climate change, some trade, etc.), competition (strategic competition in high-tech, ideology, etc.), and potential adversity (territorial issues, the military, etc.). It will have interlinked impacts on the relations to European and other countries as well. The Biden administration has the potential to be rather a temporary stagnation period, i.e., a period of waiting for history to move again in a few years. Nevertheless, it will be probably to some extent the Biden-Harris administration which can bring at least some new impulses, mainly a more cultivated approach to global multilateral interactions and domestic racial issues.

China's prospects for the next years are formulated in a much more diplomatic way in the main documents, particularly in a similar way since two of China's strategies were in relations to the parallel US documents described above. Next years, particularly from 2021 onwards, China plans to develop according to the new 14th Plan for innovative economic and social development and the long-term objectives for the year 2035. It is not only another 5-year-period of time but also the first five-year period after China achieved the first centennial objective of establishing a well-off society. It is a new phase not only for China because of global interactions.

China's cooperation within the global supply and demand chains plan to continue, now with a focus on research and innovation. It will be complemented by the philosophy of 'dual circulation' which has followed a tradition of a similar approach since the late 1970s, as I explained above. In some years, internal issues were at the centre of attention, in other years the external ones. Nevertheless, both of them were important all the time. Last years, a focus on domestic consumption is supported in order to balance domestic and foreign activities and sovereignty. Communiqué of the Fifth Plenary Session of the 19th Central Committee of the CPC declared that national security and military are important in this context and, at the same time, a concept of sovereignty is understood in relation to a proposal that 'technological independence and self-reliance should be the strategic support of the country's development' (Communique of the Fifth Plenary Session of the 19th Central Committee of the Communist Party of China., 2020).

Therefore, it deals with the relative sovereignty of core technology, which now means mainly semiconductors for the production of electronic devices. The USA was mentioned only implicitly in the main speech in the Central Committee by President Xi Jinping when he talked about the challenges of unilateralism and protectionism which were clear indications of certain country. China's concept of ecological civilisation can be in 
consensus with the new US administration and the EU concerning the Paris Agreement and related issues.

The Chinese 14th Plan deals with domestic themes because it is a domestic plan, but it also partly specifies international issues, even if in most cases in indirect ways (Proposal, 2021). Nevertheless, the interconnections are there mainly thanks to the concept of dual circulation. Therefore, an important topic of the continuation in reform and opening up is formulated, first, in terms of 'comprehensively deepening reform, and building high-level mechanisms for the socialist market economy', for example (Proposal, 2021, 13). Then, foreign and global issues are specified in the part No. XI called 'Putting high-level external opening up into practice, and exploiting new situations for win-win cooperation' (实行高 水平对外开放, 开拓合作共赢新局面) (Proposal of the Central Committee of the Chinese Communist Party on Drawing Up the 14th Five-Year Plan for National Economic and Social Development and Long-Term Aims for 2035, 2021, pp. 21-22).

The agenda is formulated as international cooperation with the aims of achieving 'mutual benefits and win-win outcomes'. It has three points: a high-level of the new open economy system, high-quality development of the Belt and Road Initiative, and the reform of the global economic governance system. ${ }^{7}$

This is to be achieved by continuing to open up in a deeper way in a broader range of areas. The first aim should be a higher level of the new open economy system. The means to achieve this should be not just more conventional production with little added value, but innovation. Trade development should be innovation-based, which should then be able to withstand the competition in foreign trade.

The construction of pilot trade zones, including the Hainan Free Trade Port, will be accompanied by greater reforms of autonomy. In the Chinese model, of course, it is not only a chaotic boundless opening up, but also a regulated opening up using an administrative system. This also includes regulations to protect domestic and foreign economic actors, particularly legitimate rights and interests according to law and new improved laws and rules. These also apply to the rights and interests of foreign companies, while at the same time to the rights and interests of Chinese companies 'Going Global'. These measures and important exhibitions, the China International

${ }^{7}$ These points, particularly Nos. 39 - 41, create three of 60 points of the Plan proposal. 
Import Expo, for example, are expected to make a more balanced trade and a higher quality of inward foreign investment. The other important point is the greater internationalisation of the Renminbi (RMB). Again, this should not be only a quantitative trend in this area but an increase in quality through new types of mutually beneficial cooperation with the free use of the Chinese currency.

The second priority of Chinese foreign interactions in the coming years is a high-quality development of the Belt and Road Initiative. It is clear that this activity tries to overcome the pitfalls of the last four years of the Trump administration, which were characterised by conflicts and little possibility of diplomatic communication. This point emphasises a principle of extensive negotiation in international cooperation, as well as a joint construction and sharing of benefits, pragmatic collaboration, and win-win production and supply chains, common development, etc. The traditional element of the Belt and Road is connectivity and infrastructure, now with a bigger focus on the digital economy. A new emphasis in connection with the current interdependence with the USA is the improvement of the diversified investment and financial system.

The third foreign priority is the reform related to the global economic governance system. Once again, win-win cooperation appears here as a basic premise based on equitable negotiations. China, as the most influential BRICS country, proposes to make full use of the G20 platform, which includes more countries than just the West-centric oriented G7. Strengthening the multilateral system in this way should lead, among other things, to reforms of the World Trade Organisation. China is striving for a global economic governance system that is more just and rational. The proposal not only builds on existing forms of the economic system but also calls for the creation of economic governance rules in order to deal with new and emerging economic fields, and bigger participation in the sphere of international financial governance.

Based on these formulations, it is clear that the Plan Draft is more restrained than the wording of the US future prospects and does not attack individual countries, regions or macro-regions of the world. The differences stem from several factors but the most important are, of course, the different diplomatic approaches of these major powers as well as the different characteristics of the documents of these countries. 


\section{EUROPE IN THE ERA OF CHANGING GLOBAL INTERACTIONS}

Various countries and macro-regions of the world have tried to address the global challenges in various ways last years. While the USA has chosen mainly to foster a unilateral confrontational approach and contain China by the trade war, technological war, diplomatic tensions and other measures, other major powers have taken more creative active approaches.

The EU and Japan have attempted to copy the main aspects of the Belt and Road Initiative and signed an agreement of cooperation between the EU and Japan in September 2019 in order to develop (rather symbolically) connectivity from the Pacific to the Balkans, being aware of positive contributions of China's global involvement and its impacts on the transformation of economic and social reality and related rules in Eurasia and at the global scale as well.

Other countries have chosen even more active and self-confident approaches and cooperate actively in an innovative way with the Belt and Road Initiative and other activities. Despite the external pressures from the USA, 15 Asian countries pursued an autonomous approach and finalised a new treaty in Asia. It is probably one of the two most significant China's achievements of the last year. The Regional Comprehensive Economic Partnership (RCEP) was signed in November 2020. It has created the biggest free trade zone in Asia, with approximately a third of global GDP and almost a third of the world's population, particularly 2.2 billion people. Member countries of China, Japan, South Korea, Australia, New Zealand and ten ASEAN members, which include, among others, Indonesia, Malaysia, the Philippines and Thailand, decided to reduce tariffs and establish new rules in trade, e-commerce and other areas of cooperation.

The second relevant achievement of the last year is the EU-China agreement on investment, signed in December 2020. It is another milestone of the China-EU cooperation. It also shows an autonomous approach of the European Union and its members in their intention to cooperate with China, and not to be limited by the US priorities. After the new US administration took power, the EU has wanted to express that it is ready to develop multilateral relations. It presented a declaration on Multilateral cooperation for global recovery, which appeared on February 2021 and was signed by Charles Michel, President of the European Council; Ursula von der Leyen, President of the European Commission; Emmanuel Macron, President of France; Angela Merkel, Chancellor of Germany; Macky Sall, President of Senegal; António Guterres, UN Secretary-General (Multilateral Cooperation 
for Global Recovery, 2021). The EU politicians are taking advantage of the momentum of change in the US administration intending to take a global initiative and reinvigorating multilateral cooperation for the future. They are trying to renew the agreement in support of an international order that would be a platform for such cooperation, including the G7 and G20.

Although traditional Western political values are also heard in the documents, the pandemic has suddenly overshadowed the classic liberal invocation of freedom. Social rights are finally at the top: 'Health is the first emergency. The Covid-19 crisis is the greatest test of global solidarity in generations. It has reminded us of an obvious fact: in the face of a pandemic, our health safety chain is only as strong as the weakest health system. Covid19 anywhere is a threat to people and economies everywhere' (Multilateral Cooperation for Global Recovery, 2021). If health and human lives come first, now it will be indeed easier to find consensus between the European Union and other countries and macro-regions of the world, especially with countries in conflict zones and post-conflict and developing countries where poverty is often widespread. The document states that instead of the clash of civilisations and their values, common values are now emphasised, while human rights are not specified which opens up space for emphasis on social and economic rights. 'Rather than pitting civilisations and values against each other, we must build a more inclusive multilateralism' (Multilateral Cooperation for Global Recovery, 2021).

The document also focuses on the new character of interactions in today's digital age. It outlines the need for taxation of digital multinational corporations and the fight against tax competition between states which has previously proved to be a race to the bottom. It is opposed by a 'safe, free and open digital environment'. The framework of this document was given already by political guidelines for the new European Commission 2019-2024, as presented by the President of the European Commission Ursula von der Leyen in A Union that strives for more in 2019. In the part called 'A Europe fit for the digital age', it addresses 'technological sovereignty in some critical technology areas' (Leyen, 2019, part 3).

This theme was further specified by Charles Michel, President of the European Council, in his speech Recovery Plan: powering Europe's strategic autonomy in 2020: 'The strategic independence of Europe is our new common project for this Century ... European strategic autonomy is goal number one for our generation. For Europe, this is the real start of the 21st Century' (Michel, 2020). Then, he continued in his talk Digital sovereignty is central to European strategic autonomy in 2021 (Michel, 2021). 
Strategic autonomy is a manifestation of cyber security which represents digital sovereignty as European strategic autonomy. ${ }^{8}$ The concept of 'strategic autonomy' 'means more resilience, more influence. And less dependence. We want greater autonomy and greater independence in an open and global environment. This means reducing our dependencies, to better defend our interests and our values. We want a more level playing field and more fairness in today's globalized world. Interdependence is natural, even desirable. Over-dependence, however, is not. So, strategic autonomy has nothing to do with protectionism. On the contrary' (Michel, 2021). Some other European politicians support a similar idea as well. In military issues, there has been a discussion on the EU strategic autonomy since the Balkan war in the 1990s and the Iraq War in 2003 when various countries in Europe criticised these illegal US interventions. Last years, discussions went beyond defence and security issues and dealt also with economic and technological autonomy. It is an attempt to adapt to the worse global conditions caused by the US trade frictions with China and the pandemic trade shortages. However, it is not only a reaction to negative trends. It is also a general tendency to integrate into a new digital level of global technological development and secure the positions of the countries and macro-regions.

There is an effort to pursue strategic autonomy in the internal development within the EU and, at the same time, develop a balanced relationship with other partners beyond the EU in global interactions. The concept of strategic autonomy in a narrower sense can be understood as a parallel to the above-mentioned Chinese concept of sovereignty in technological independence and self-reliance, and, more broadly, in relation to the 'Made in China 2025' program. This can be also considered a part of the European version of dual circulation, therefore, not limited to the topic of technological or digital sovereignty but also applied to production, trade and other spheres of the European Union.

\footnotetext{
${ }^{8}$ There is a connection to the previous digital regulation: the General Data Protection Regulation (GDPR) from 2016, and the proposed Digital Services Act and Digital Markets Act. It can also be considered in connection to the construction of autonomous satellite systems: the European satellite network Galileo and the GSA is of the EU autonomy in relation to GPS operated by the USA. China has developed its own navigation satellite system (BDS) BeiDou in a parallel way; Russia has made GLONASS, etc.perceived as a source.
} 
Dependence in the digital sphere is also perceived here due to the danger of 'the abuse of personal data'. It is formulated in relation to large digital corporations, due to 'the overexploitation of data ... in pursuit of profit' (Michel, 2021). In this context, nevertheless, it is not explicitly mentioned that this means mainly US companies and the US government which stands for them abroad, including Europe. Concerns are also expressed about the political use of data by China, which, however, is explicitly mentioned. Unfortunately, the double standard is still being enforced.

The concept of strategic autonomy has been already partly misused in political, economic and other areas in the EU. Following the US-China trade and technological frictions, there have been problematic strategic tendencies in the sphere of health, for example. In the European Union, the current problems, which are related to high-tech in connection with vaccination against COVID-19, on the one hand, can be seen in the West-centric ideological blockade of non-Western companies which also have made research and production of vaccines. The ideological limitations and the profits of firms based in Western countries had a higher priority than human lives and health when the vaccination process started in the EU. On the other hand, this bias has not been present in all European countries. Some EU countries (Hungary, Italy, for example), as well as some non-EU countries (Serbia, for example), have called for an open multilateral approach and negotiations with several countries around the world that have been able to invent and produce COVID-19 vaccines, including Russia and China. After Western big pharma-companies were even unable to use their oligopoly position and failed to deliver vaccines in the promised required numbers, fortunately, these European countries began to act multilaterally in order to negotiate the approval of vaccines made by Russian and Chinese companies and their supply in the EU in order to safe human lives. This is certainly a good sign for overcoming the Eurocentric and West-centric world and, conversely, for strengthening multilateralism in Europe and on a global scale.

The countries of Central and Eastern Europe (CEEC), which are involved in the $17+1$ Cooperation with China, play a positive role in promoting multilateralism. The ninth Summit of the $17+1$ Cooperation proved it. Originally planned for 2020, it had to be postponed because of the COVID19 pandemic. Finally, it took place online in February 2021 and showed good results of the previous period, and new prospects for the future. The total trade volume between China and CEEC exceeded 100 billion USD for the first time in 2020. The Summit presented cooperation in various areas: trade, environmental issues, research, health care, including the delivery of 
medical equipment and products such as face masks and vaccines. Serbia, Hungary and other countries of the $17+1$ Cooperation have been really active also in the pandemic times, pursuing cooperation via 'cloud diplomacy' in online meetings. The countries of Central, Eastern and Western Europe, which are involved in the Belt and Road Initiative, have also played a similar cooperative and multilateral role.

\section{CONCLUSION}

The main contribution of this article is an analysis of several relevant points, which are usually less stressed in other analyses. It shows the historical process of building Chinamerica and following fragmenting Chinamerica when the Trump administration brought technological, trade and diplomatic frictions as well as the ultimate threat of military escalation via an establishment of political and technological capabilities of limited nuclear war. It explains the origins of the Chinese concept of dual circulation and its update which is in relation to the ambivalent concept of strategic autonomy used by the European Union and similar concepts used by other major powers. It plays an important role in the multilateral adaptation of major powers to the worse global conditions set up by the Trump administration. The article illuminates these trends by its focus on new documents and speeches presented by representatives of the USA, China, and the EU.

Specifically, the analysis of fragmenting Chinamerica and its global consequences with an impact on Europe brings more light on the current process of multilateral transformation of the global system, mainly its political, economic, technological and security aspects. The reality and the key strategic documents and speeches presented by representatives and organisations of the USA and China show how a turn from a historical process of development of Chinamerica has taken place. It also partly decoupled the USA from Europe and other parts of the world, and worsened global interactions, including a possible military escalation, ultimately limited nuclear war, with the US rivals. The Trump administration's trade, technological, diplomatic and other tensions have partly survived in the Biden administration (China as the 'most serious competitor', trade tariffs, territorial interferences, etc.) even if in a more cultivated and more multilaterally oriented way. This transitory US period defined by the term of Biden's administration starts at the same time when China enters a new period of development from 2021 to 2025 and to 2035. 
To conclude, more complex global interactions than in the past will probably appear in the next years. It means neither greater linear globalization nor de-globalization but a complex development. We can expect new specific coopetition, i.e., a new version of the joint cooperation and competition within the new strategic limits. These limits are expected to be defined not by Trump's confrontational unilateral tendencies, as was originally the case, but by more intersubjective interactions among more players. The lines, enforced first by the USA, then reformulated by China, and later also by the EU, are reflected and specified also in other parts of the world now. The more complex global relations based on more organisational levels include a bigger relative strategic sovereignty of major powers and other countries in one of these levels. It can be articulated by a concept of strategic autonomy if we use the European term. Strategic autonomy, which recently stems from an idea of sovereignty in cyber security and other security areas, is close to the Chinese concept of sovereignty in technological independence and self-reliance and, in a more general way, to the concept of dual circulation which also operates with internal and external spheres of activities. It is a call of the major powers for more resilience and less strategic dependence but within global cooperation and competition.

European countries, the USA, China and others learned the value of sovereignty which fully or partly lost but won again during World War II. China knows the value of sovereignty based on another event in its history as well. This year 2021 is Xin Chou in the Chinese lunar calendar, commemorating a significant anniversary. Exactly two full cycles (a cycle repeats every 60 years.) of the Chinese lunar calendar ago, i.e., 120 years ago in Xin Chou in 1901, China lost its sovereignty in the anti-imperial Boxer Rebellion against the Western powers. But then the waves of modernisation began in China in 1911, 1949, and 1978, and China got its sovereignty again. Last four decades, China was able to do both: to make internal development and engage successfully in global interactions even if it was not easy. After the decades of the West-led globalization, particularly since the 2008 global economic and financial crisis which showed the lack of inclusivity of this version of globalization, the relationships between domestic and global development have been in the painful process of redefinition in many parts of the world again, especially last years. The USA, China, the EU and others have learned step by step in this process how to keep its own strategic sovereignty in economic, political, technological, security and other disputes and how to develop shared sovereignty in other areas in the new digital level of global interactions. 
Even if strategic autonomy has been also misused in order to limit cooperation, there are good possibilities to develop multilateral cooperation between China, the USA, the European countries and other parts of the world based on mutual recognition. Win-win economic, political, technological, research, ecological and intercultural kinds of cooperation can be pursued by the European countries within the bilateral and multilateral relations, specifically within the United Nations, the Belt and Road Initiative, and the $17+1$ Cooperation. There are also other organisations that play a positive role in developing multilateral cooperation, such as the Shanghai Organisation of Cooperation, the Eurasian Union, etc. Moreover, it is not limited to Eurasia. In global interactions, the Belt and Road Initiative is developed also in Africa by the means of FOCAC, in Latin America by the means of China-CELAC Cooperation, etc. Nevertheless, the new strategic lines of global interactions with various tensions will require overcoming challenges and crises in the post-pandemic times.

\section{REFERENCES}

American Observer. (2021, February 6). U.S. trade deficit surges to 12-year high in 2020 amid COVID-19 fallout, retrieved from http:/ / american observer.com/2021/02/06/u-s-trade-deficit-surges-to-12-year-high-in2020-amid-covid-19-fallout/. Accessed 7 February 2021.

Biden, J. (2021a, January 20). Inaugural Address by President Joseph R. Biden, Jr, retrieved from https://www.whitehouse.gov/briefingroom/speeches-remarks/2021/01/20/inaugural-address-by-presidentjoseph-r-biden-jr/. Accessed January 22, 2021.

Biden, J. (2021b, February 21). Transcript: President Joe Biden delivers foreign policy speech, retrieved from https://asia.nikkei.com/Politics/ Transcript-President-Joe-Biden-delivers-foreign-policy-speech. Accessed 22 February 2021.

Blinken, A. (2021, March 3). A Foreign Policy for the American People, retrieved from https://www.state.gov/a-foreign-policy-for-theamerican-people/. Accessed 4 March 2021.

Brode, H. L. (2014). Nuclear Weapons in the Cold War. North Charleston, CreateSpace Independent Publishing Platform.

China and the World in the New Era. (2019). Beijing, The State Council Information Office of the People's Republic of China. 
China's National Defence in the New Era. (2019). Beijing, The State Council Information Office of the People's Republic of China, Foreign Languages Press.

Communique of the Fifth Plenary Session of the 19th Central Committee of the Communist Party of China. (2020, October, 29), retrieved from http://www.xinhuanet.com/politics/2020-10/29/c_1126674147.htm. Accessed 22 January 2021.

Cordesman, A. H. (2019). China's New 2019 Defence White Paper. An open strategic challenge to the United States, but one which does not have to lead to conflict, retrieved from https:// www.csis.org/analysis/chinasnew-2019-defense-white-paper. Accessed 22 January 2021.

Craig, C.\&Radchenko, S. (2008). The Atomic Bomb and the Origins of the Cold War. New Haven, Yale University Press.

Cvetković, V. (2016). The One Belt, One Road. The Balkan Perspective. Political and Security Aspects. Belgrade, University of Belgrade, Faculty of Security Studies.

Cvetković, V. (2018). The New Silk Road: European Perspectives. Security Challenges/Risks within the Initiative 16+1. Belgrade, University of Belgrade, Faculty of Security Studies.

Ferguson, N. (2008). The Ascent of Money. London, The Penguin Press.

Gaddis, J.L. (2006). The Cold War: A New History. London, Penguin Books.

Góralczyk, B. (2018). Wielki renesans. Chinska transformacja i jej konsekwencje [Great Renaissance: Chinese Transformation and Its Consequences]. Warszawa, Wydawnictwo Dialog.

Hrubec, M. (2019). Threat of Limited Nuclear War. Critical Sociology, Vol. 45 (No. 6), pp. 785-798.

Hrubec, M. (2020). From China's Reform to the World's Reform. International Critical Thought, Vol. 10 (No. 2), pp. 282-295.

Interim National Security Strategic Guidelines. (2021) Washington, D.C., The White House.

Jones, H. (2020). Chinamerica: The Uneasy Partnership that Will Change the World. New York, McGraw-Hill Education.

Larsen, J. A. (2014). Limited war and the advent of nuclear weapons, in: J.A. Larsen\&K.M. Kartchner (Eds.), On Limited Nuclear War in the 21st Century (pp. 3-20). Stanford, Stanford University Press.

Leyen, van der U. (2019). A Union that strives for more - My agenda for Europe. Political guidelines for the next European Commission 2019- 
2024, retrieved from https://ec.europa.eu/info/sites/info/files/ political-guidelines-next-commission_en_0.pdf.

Li, D. et al. (2018). Economic Lessons Learned from China's Forty Years of Reform and Opening Up. Beijing, Tsinghua University Press.

Mahbubani, K. (2014). The Great Convergence. New York, Public Affairs.

Michel, C. (2020, September 8). Recovery Plan: powering Europe's strategic autonomy, retrieved from https://www.consilium.europa.eu/en/ press/press-releases/2020/09/08/recovery-plan-powering-europe-sstrategic-autonomy-speech-by-president-charles-michel-at-the-brusselseconomic-forum/. Accessed 25 February 2021.

Michel, C. (2021, February 3). Digital sovereignty is central to European strategic autonomy - Speech by President Charles Michel at 'Masters of digital 2021' online event, retrieved https:/ / www.consilium.europa. $\mathrm{eu} / \mathrm{en} /$ press/press-releases/2021/02/03/speech-by-president-charlesmichel-at-the-digitaleurope-masters-of-digital-online-event/. Accessed 05 February 2021.

Multilateral cooperation for global recovery. (2021, February 3), retrieved from https://www.consilium.europa.eu/en/press/press-releases/2021 /02/03/rebuilding-consensus-for-an-international-rules-based-orderthrough-multilateral-cooperation/. Accessed 04 February 2021.

National Security Strategy of the United States of America. (2017). Retrieved from https:/ / www.whitehouse.gov/wp-content/uploads/2017/12/ NSS-Final-12-18-2017-0905.pdf. Accessed 29 August 2018.

Nolan, P. (2019). China and the West: Crossroads of Civilization. New York, Routledge.

Obama, B. (2013). 2009 Obama speech in Prague. Bulletin of the Atomic Scientists, retrieved https://thebulletin.org/multimedia/2009-obamaspeech-prague. Accessed 29 August 2018.

Pee, R. (2015). Democracy Promotion, National Security and Strategy: Foreign Policy under the Reagan Administration. London, Routledge.

Pompeo, M. R. (2020). Communist China and the Free World's Future, retrieved from https://china.usembassy-china.org.cn/communistchina-and-the-free-worlds-future/. Accessed 24 January 2021.

Proposal of the Central Committee of the Chinese Communist Party on Drawing Up the 14th Five-Year Plan for National Economic and Social Development and Long-Term Aims for 2035 [（授权发布）中共中央关 于制定国民经济和社会发展第十四个五年规划和二 $\mathrm{O}$ 三五年远景目标 
的建 议 ] (2021), retrieved from https://web.archive.org/web/ 20201104114039/http://www.xinhuanet.com/politics/zywj/202011/03/c_1126693293.htm. Accessed 22 January 2021.

Richard, A. C. A. (2021). U.S. Navy. Forging 21st-Century Strategic Deterrence, retrieved from https://www.usni.org/magazines/ proceedings/2021/february/forging-21st-century-strategic-deterrence.

Rhodes, R. (2012). The Making of the Atomic Bomb. London, Simon \& Schuster.

Suri, J.\&Valentino, B. (Eds.) (2016). Sustainable Security: Rethinking American National Security Strategy. Oxford, Oxford University Press.

The Summary of the 2018 National Security Strategy of the USA. (2018). Washington, D.C., Department of Defence of the USA.

U.S.' continued deception, deflection, politicization. (2021, February 14), retrieved from https://news.cgtn.com/news/2021-02-14/U-Scontinued-deception-deflection-politicization-XSjHOtfkHK/index.html. Accessed 15 February 2021.

U.S. Department of Defence (2018). Nuclear Posture Review 2018, retrieved from https:// www.defense.gov/News/SpecialReports/2018Nuclear PostureReview.aspx. Accessed 29 August 2018.

U.S. Military, Department of Defence, U.S. Government (2010). American Nuclear Posture Review. Washington, D.C., Progressive Management.

Vogel, E. F. (1992). The Four Little Dragons: The Spread of Industrialization in East Asia. Cambridge, Harvard University Press.

Wang, W. (2015a). Social Change in Contemporary China and the Theory of Social Contradictions. Reading, UK, Paths International and China Social Sciences Press.

Wang, W. (2015b). Social Interests and Conflict: A Socialist Analysis of Contemporary China. Reading, UK, Paths International and China Social Sciences Press.

Wei, X. (2010). Rethinking China's Economic Transformation. New York, Global Scholarly Publications.

Wright, T. (2020, July 27). Pompeo's surreal speech on China, retrieved from https://www.brookings.edu/blog/order-from-chaos/2020/07/27/ pompeos-surreal-speech-on-china/. Accessed 22 January 2021.

Xi, J. (2017). The Governance of China, Vol. 2. Beijing, Foreign Languages Press. 